\title{
Bidirectional Flyback Converter with Multiple Series Connected Outputs for High Voltage Capacitive Charge and Discharge Applications
}

Thummala, Prasanth; Schneider, Henrik; Zhang, Zhe; Andersen, Michael A. E.

Published in:

Proceedings of 30th Annual IEEE Applied Power Electronics Conference and Exposition

Link to article, DOI:

10.1109/APEC.2015.7104331

Publication date:

2015

Document Version

Peer reviewed version

Link back to DTU Orbit

Citation (APA):

Thummala, P., Schneider, H., Zhang, Z., \& Andersen, M. A. E. (2015). Bidirectional Flyback Converter with Multiple Series Connected Outputs for High Voltage Capacitive Charge and Discharge Applications. In Proceedings of 30th Annual IEEE Applied Power Electronics Conference and Exposition (pp. 50-56). IEEE. https://doi.org/10.1109/APEC.2015.7104331

\section{General rights}

Copyright and moral rights for the publications made accessible in the public portal are retained by the authors and/or other copyright owners and it is a condition of accessing publications that users recognise and abide by the legal requirements associated with these rights.

- Users may download and print one copy of any publication from the public portal for the purpose of private study or research.

- You may not further distribute the material or use it for any profit-making activity or commercial gain

- You may freely distribute the URL identifying the publication in the public portal 


\title{
Bidirectional Flyback Converter with Multiple Series Connected Outputs for High Voltage Capacitive Charge and Discharge Applications
}

\author{
Prasanth Thummala, Henrik Schneider, Zhe Zhang and Michael A. E. Andersen \\ Electronics Group, Department of Electrical Engineering \\ Technical University of Denmark \\ Kongens Lyngby, DK-2800 Denmark \\ Web: http://www.ele.elektro.dtu.dk/ \\ Email: pthu@elektro.dtu.dk, hensc@elektro.dtu.dk
}

\begin{abstract}
This paper evaluates two different implementations of a bidirectional flyback converter for driving a capacitive electro active actuator, which must be charged and discharged from $0 \mathrm{~V}$ to $2.5 \mathrm{kV}$ DC and vice versa, supplied from a 24 $\mathrm{V}$ battery. In one implementation, a high voltage MOSFET (4 $\mathbf{k V}$ ) in series with a high voltage blocking diode is added, in parallel with a high voltage freewheeling diode of a conventional flyback topology, to enable bidirectional operation. Experimental result from a digitally controlled bidirectional flyback converter shows that the discharge energy efficiency is limited by the parasitics of the high voltage active components, which also prevent full utilization of valley switching during discharge process. A second implementation is therefore proposed, where the secondary of flyback transformer winding is split into multiple windings which are connected in series by lower voltage rating MOSFETs driven by a gate drive transformer. Simulation results to compare the operation of conventional and proposed converters are provided. The advantages of proposed implementation are improved energy efficiency and lower cost. Experimental results with two series connected secondary windings are provided to validate the proposed implementation.
\end{abstract}

\section{NOMENCLATURE}

$C_{\text {in }} / C_{\text {load }}$
$C_{\text {ossp }}$
$C_{\text {osss }}$
$C_{\text {osss } 1}$
$C_{j}$
$C_{s}$
$C_{s 1}$
$D_{2}$
$D_{b}$

Input capacitance / Load capacitance.

Balancing capacitor across a series combination of one of the splitted secondary winding and a secondary MOSFET.

Output capacitance of the low voltage MOSFET $M_{p}$.

Output capacitance of the high voltage MOSFET $M_{s}$.

Output capacitance of one of the several series connected MOSFETs $\left(M_{s 1}\right)$ on the secondary high voltage side.

Junction capacitance of the high voltage diodes $D_{2}$ or $D_{b}$.

Self capacitance of secondary high voltage winding of the flyback transformer.

Self capacitance of one of the secondary high voltage splitted windings of the flyback transformer.

High voltage $(5 \mathrm{kV})$ freewheeling diode which conducts while charging the capacitive load. High voltage $(5 \mathrm{kV})$ blocking diode which conducts while discharging the capacitive load.

$D_{b p} / D_{b s} \quad$ Body diode of the MOSFET $M_{p} / M_{s}$.

$D_{b s 1} \quad$ Body diode of one of the several series connected MOSFETs $\left(M_{s 1}\right)$ on the secondary high voltage side.

$i_{\text {in }} / i_{p} / i_{s} \quad$ Input / Primary / Secondary current.

$i_{\text {load }} \quad$ Current through the load.

$L_{m p} / L_{m s}$ Primary / Secondary magnetizing inductance of a non-splitted flyback transformer.

$L_{m s 1} \quad$ Secondary magnetizing inductance of one of the splitted winding of the flyback transformer.

$L_{l k p} / L_{l k s} \quad$ Leakage inductance referred to primary / secondary of a non-splitted flyback transformer.

$L_{l k s 1} \quad$ Leakage inductance referred to secondary of one of the splitted winding of the flyback transformer.

$M_{p} / M_{s} \quad$ Low voltage / High voltage $(4 \mathrm{kV})$ MOSFET.

$M_{s 1} \quad$ One of the several series connected MOSFETs on the secondary high voltage side.

$n \quad$ Turns ratio from secondary to primary of the non-splitted flyback transformer.

$n_{1} \quad$ Turns ratio from one of the splitted secondary to primary of the splitted flyback transformer.

$N_{p} / N_{s} \quad$ Number of primary / secondary turns of the non-splitted flyback transformer.

$N_{s 1} \quad$ Number of secondary turns on one of the splitted secondary winding of the flyback transformer.

$R_{p} / R_{s} \quad$ DC resistance of low voltage / high voltage winding of the transformer.

$R_{s 1} \quad$ DC resistance of one of the splitted secondary high voltage winding of the flyback transformer.

$V_{D b} / V_{D 2} \quad$ Voltage across the high voltage $(5 \mathrm{kV})$ blocking / freewheeling diode.

$V_{M p} / V_{M s}$ Voltage across the low voltage / high voltage (4 kV) MOSFET.

$V_{M s 1} \quad$ Voltage across one of the several series connected MOSFETs $\left(M_{s 1}\right)$ on the secondary high voltage side.

$V_{\text {in }} / V_{\text {out }}$ Input voltage / Output or load voltage. 


\section{INTRODUCTION}

Dielectric electro active polymer (DEAP) is an emerging smart material that has experienced substantial improvement and has gained increasing attention over the last decade from the researchers [1]-[3]. The DEAP material is a very thin (40 $\mu \mathrm{m})$ incompressible silicone elastomer film with a compliant electrode layer on both sides [5], [7]. DEAP can be considered as a pure capacitive load from an electrical perspective [6]. The basic behaviour of the DEAP actuator is the reduction in the polymer thickness and the increment in its area, due to an applied electric field $(40-60 \mathrm{~V} / \mu \mathrm{m})$ [7], [8]. The axial DEAP actuator as shown in Fig. 1 is ideally equivalent to a capacitive load. When a DEAP actuator is driven with high voltage $(2-2.5 \mathrm{kV})$, it converts a portion of the electrical energy into mechanical displacement, which is of the order of mm (1$1.5 \mathrm{~mm}$ ) [4], [5]. Three of such axial DEAP actuators are used to create a DEAP incremental actuator [9] as shown in Fig. 2. DEAP, when used as linear incremental actuators, has the potential to be an effective replacement for many conventional (e.g., piezo, pneumatic and hydraulic) linear actuators due to its unique properties such as large strain, light weight, and high flexibility.

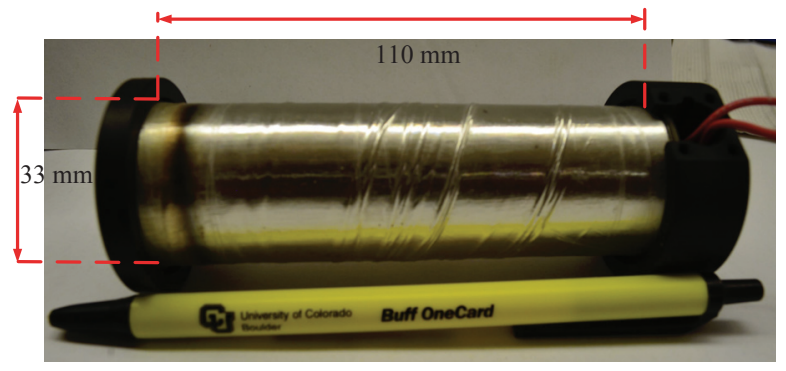

Fig. 1. A linear DEAP actuator manufactured by Danfoss PolyPower A/S.

The DEAP actuator applications [10], [11] require high voltage (HV) bidirectional power electronic converters, to charge and discharge the actuator, and to transfer part of the energy stored in it to the source. Switch-mode power supplies for charging the capacitive loads have been implemented in [12]-[15]. The flyback converter is suitable for low power $(<150 \mathrm{~W})$ and high voltage $(2.5 \mathrm{kV})$ applications, due to its simple structure and low component count [16]. In [17], [30], [32]-[36], [44], [45] bidirectional flyback converters with various power stages and control techniques, for charging and discharging DEAP actuators have been proposed and implemented. The proposed converter with multiple series con-

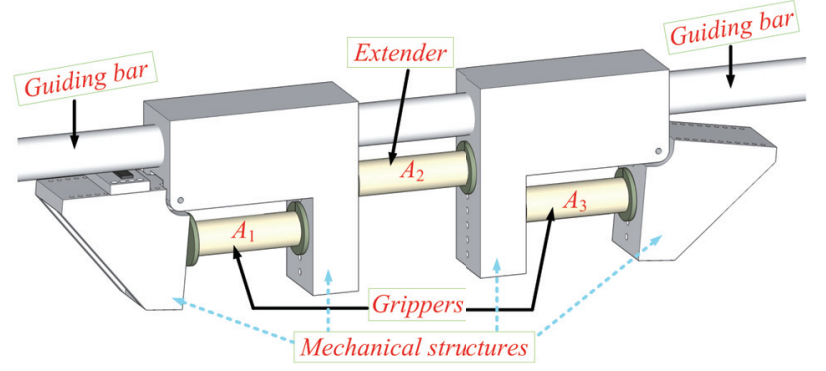

Fig. 2. A DEAP incremental actuator. nected secondary windings is different from aforementioned converters, since it is aimed for bidirectional operation, by replacing the diode with a MOSFET on the secondary HV side. This paper is organized as follows: Section II describes the conventional and proposed HV drivers. Section III provides the simulation results. Section IV discusses the gate driver for the secondary HV side. Section V provides the experimental results and efficiency measurements. Section VI concludes the paper followed by the futur work in Section VII.

\section{High Voltage Drivers: CONVENTIONAL AND PROPOSED}

High efficient flyback based converters have been widely investigated and implemented by several researchers [18]-[24]. Several bidirectional flyback converter topolofies have been proposed and implemented in [25]-[29]. The conventional high voltage bidirectional flyback converter [30], [31], for driving (charging and discharging) a DEAP actuator with a certain actuation frequency, is shown in Fig. 3.

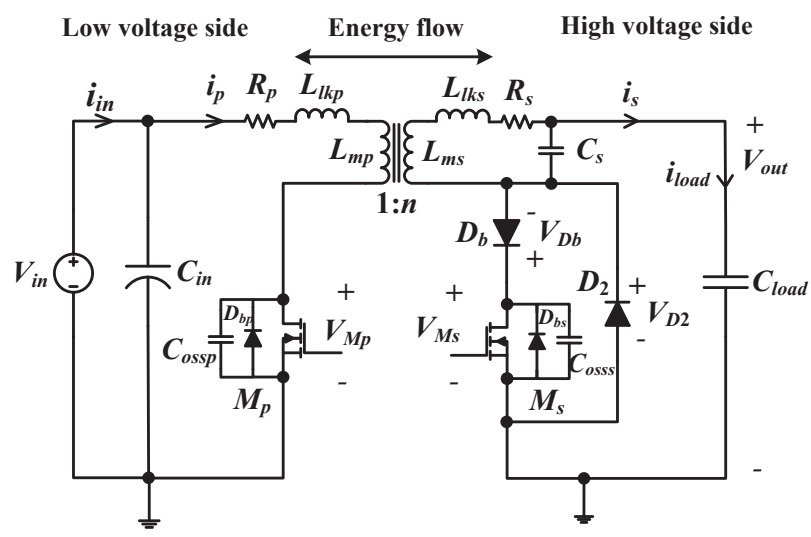

Fig. 3. Conventional HV bidirectional flyback converter.

An efficiency optimization technique has been proposed in [32], [33] to improve the energy efficiency of the converter. Investigation of different transformer winding architectures (TWAs) for the same topology has been proposed in [34]. A new digital control technique to achieve the valley switching during both charge and discharge processes in a bidirectional flyback converter is proposed in [35], for better energy efficiency and improved charge and discharge speed. Primary parallel, secondary series flyback converter with multiple transformers is proposed in [36], to reduce the equivalent selfcapacitance on the secondary HV side. The HV converter used in [9], [30], [32], [35], requires a HV (4 or $4.5 \mathrm{kV})$ MOSFET $M_{s}$ and two HV $(5 \mathrm{kV})$ diodes $D_{2}$ and $D_{b}$ as shown in Fig. 3.

The $4 \mathrm{kV}, 300 \mathrm{~mA}$ high voltage IXYS MOSFET [37] has the following features:

- $\quad$ high on-resistance of $290 \Omega$.

- $\quad$ high output capacitance of $19 \mathrm{pF}$.

- $\quad$ high reverse recovery time of $2.8 \mu \mathrm{s}$.

The $5 \mathrm{kV}, 150 \mathrm{~mA}$ VMI high voltage diode [38] has the following features: 
- $\quad$ on-state voltage drop of $7 \mathrm{~V}$.

- junction capacitance of $3 \mathrm{pF}$.

- reverse recovery time of $70 \mathrm{~ns}$.

Therefore, using a HV MOSFET $M_{s}$ and two HV diodes $D_{2}$ and $D_{b}$ on the secondary side of the HV bidirectional DCDC converter, make it very expensive and inefficient.

To reduce the voltage rating of the high voltage MOSFETs, series input and parallel output DC-DC converters have been proposed and implemented in [39]-[43]. The proposed HV bidirectional flyback converter is shown in Fig. 4. Using this topology, it is possible to series connect several lower voltage $(<4 \mathrm{kV})$ rated MOSFETs each having a better body diode (with less reverse recovery time).

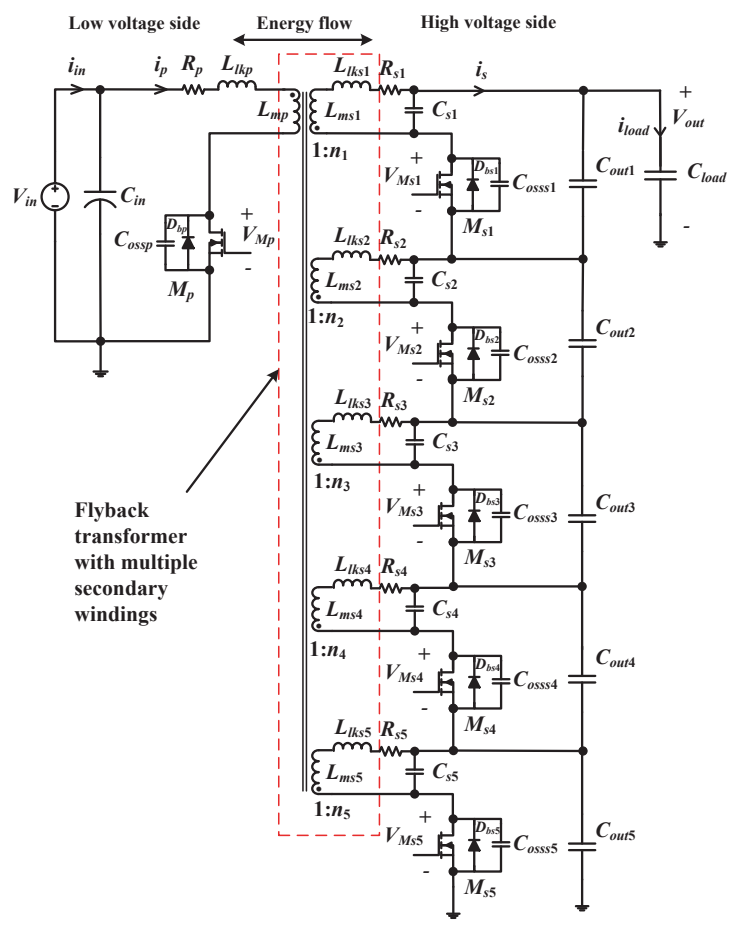

Fig. 4. Proposed HV bidirectional flyback converter with 5 series connected secondary transformer windings and MOSFETs on the secondary HV side.

The advantages of the proposed topology are:

- reduction in the voltage rating and price of the HV MOSFET.

- $\quad$ elimination of blocking and freewheeling HV diodes.

- $\quad$ possibility to achieve perfect valley switching of HV MOSFET, unlike the semi-valley switching [35] (due to series connection of HV diode $D_{b}$ and HV MOSFET $M_{s}$ during the discharge process).

- improved overall (charge and/or discharge) energy efficiency.

However, the difficulties associated with the proposed converter are:
- the need of high side gate drivers for driving some of the secondary MOSFETs.

- $\quad$ synchronous switching of secondary MOSFETs.

- voltage sharing among the secondary windings and the secondary MOSFETs.

\section{Simulation Results}

Simulations have been performed in pSpice software to validate the proposed method, and the results are provided in Figs. 5 and 6.
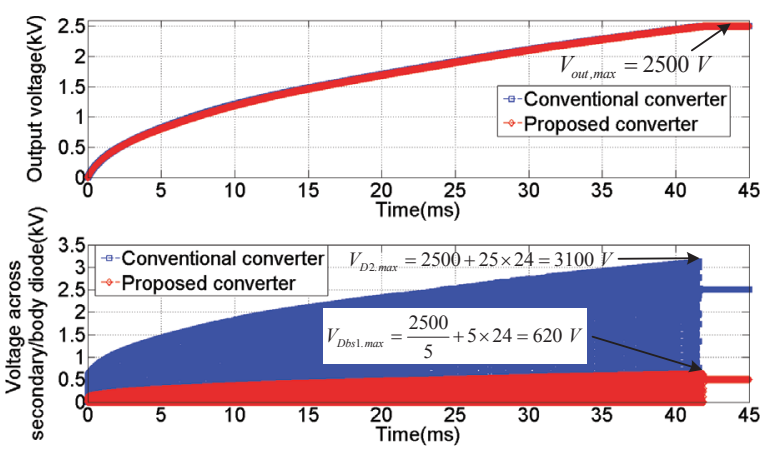

Fig. 5. Simulation results during charge process for $p=5$ stages.

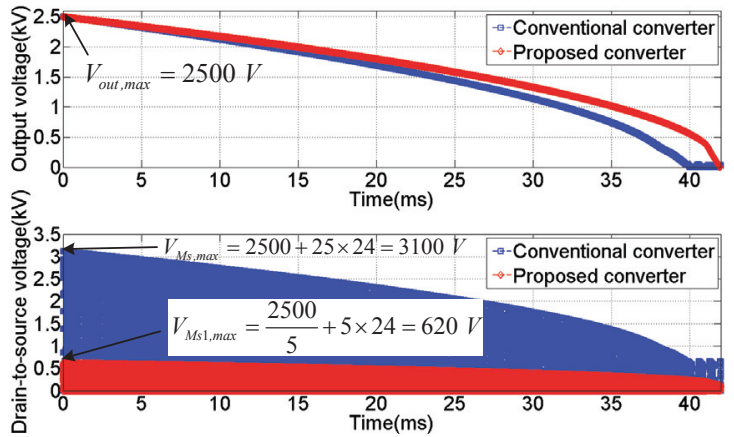

Fig. 6. Simulation results during discharge process for $p=5$ stages.

The simulation parameters used for the conventional flyback converter (Fig. 3) are: $V_{i n}=24 \mathrm{~V}, C_{\text {load }}=400 \mathrm{nF}, L_{m p}=48$ $\mu \mathrm{H}, L_{m s}=30 \mathrm{mH}, R_{p}=60 \mathrm{~m} \Omega, n=25, R_{s}=13 \Omega$. Peak current control has been implemented during both charge (with current limit 5 A) and discharge (with current limit 200 $\mathrm{mA}$ ) processes with a fixed time period of $22 \mu \mathrm{s}$ (switching frequency $f_{s w}=45.54 \mathrm{kHz}$ ). The simulation parameters used for the proposed flyback converter (Fig. 4) are the same as above, except the turns ratio $\left(n_{1}=5\right)$ and the secondary magnetizing inductance $\left(L_{m s 1}=1.2 \mathrm{mH}\right)$. In the simulations, the leakage inductance and self-capacitance are ignored and ideal switches and diodes are being used. Figure 5, provides the comparison between the output voltages, and the voltage across the secondary $\mathrm{HV}$ free wheeling diode $V_{D 2}$, and body diode $V_{M s 1}$, for the conventional and proposed converters, 
during charge process. Figure 6, provides the comparison of the output voltages and the drain-to-source voltage across the secondary MOSFET, for the conventional and proposed converters, during discharge process.

When $p$ series connected transformer and MOSFET stages are used in the secondary HV side of the proposed converter:

- the turns ratio $n_{1}$ is reduced by $p$.

- $\quad$ the magnetizing inductance $L_{m s 1}$ is reduced by $p^{2}$.

- the drian-to-source across the body diode of the secondary MOSFETs during the charge process is reduced by $p$.

- the drian-to-source across the secondary MOSFETs during the discharge process is reduced by $p$.

Hence, to charge and discharge the capacitive load to and from $2.5 \mathrm{kV}$ output voltage, the $4 \mathrm{kV}$ or $4.5 \mathrm{kV}$ MOSFET on the secondary HV side, could be easily replaced by a $800 \mathrm{~V}$ MOSFET, when $p=5$ stages are used in the secondary side.

Table I provides the comparison between the conventional and proposed converters in terms of losses due to the HV active components (at the maximum output voltage during both charge and discharge modes). Table II provides the comparison between the conventional and proposed converters in terms cost and the volume occupied, when the real MOSFETs and $\mathrm{HV}$ diodes are used in the converter.

TABLE I. LOSS COMPARISON BETWEEN THE CONVENTIONAL AND PROPOSED CONVERTERS

\begin{tabular}{l|l|l|l}
\hline \hline $\begin{array}{l}\text { Converter } \\
\text { Type }\end{array}$ & $\begin{array}{l}\text { Loss during } \\
\text { charge process }(\mathbf{W})\end{array}$ & $\begin{array}{l}\text { Loss during } \\
\text { discharge process }(\mathbf{W})\end{array}$ & $\begin{array}{l}\text { Total } \\
\text { loss }(\mathbf{W})\end{array}$ \\
\hline \hline Conventional & $L_{1}=0.168$ & $\begin{array}{l}L_{3}=0.133 \\
L_{4}=4.9\end{array}$ & 5.201 \\
& & $L_{5}=0.61$ & \\
\hline Proposed & $L_{2}=0.192$ & 0.8 \\
\hline \hline
\end{tabular}

TABLE II. COST AND VOLUME COMPARISON BETWEEN THE CONVENTIONAL AND PROPOSED CONVERTERS

\begin{tabular}{|c|c|c|c|c|}
\hline $\begin{array}{l}\text { Converter } \\
\text { Type }\end{array}$ & $\begin{array}{l}\text { Cost }(\$) \\
{ }^{*} \text { low quantity } \\
\text { prices }\end{array}$ & $\begin{array}{l}\begin{array}{l}\text { Volume } \\
\text { occupied } \\
\left(\mathrm{mm}^{3}\right)\end{array} \\
\end{array}$ & $\begin{array}{l}\text { Total } \\
\text { cost } \\
(\$)\end{array}$ & $\begin{array}{l}\text { Total } \\
\text { volume } \\
\left(\mathrm{mm}^{3}\right)\end{array}$ \\
\hline Conventional & $\begin{array}{l}20\left(^{*} 10 \text { for each }\right. \\
\text { HV diode) } \\
{ }^{*} 30 \text { (HV MOSFET) }\end{array}$ & $\begin{array}{l}128(64 \text { each } \\
\text { diode) } \\
1034 \text { (MOSFET) }\end{array}$ & 50 & 1162 \\
\hline Proposed & $\begin{array}{l}5 \text { (1 for each } \\
\text { MOSFET), } 3 \text { (for gate } \\
\text { driver) }\end{array}$ & $\begin{array}{l}440 \text { (88 each } \\
\text { MOSFET), } \\
560 \text { (gate driver) }\end{array}$ & 8 & 1000 \\
\hline
\end{tabular}

In Table I the loss expressions are given by:

$L_{1}=i_{\text {avg } C} V_{\text {onD2 } 2}$ (for $\mathrm{HV}$ diode $D_{2}$ );

$L_{2}=p i_{a v g C} V_{\text {onDbs }}$ (for $p=5 \mathrm{HV}$ body diodes);

$L_{3}=i_{a v g D} V_{o n D b}\left(\right.$ for $\mathrm{HV}$ diode $\left.D_{b}\right)$;

$L_{4}=i_{r m s D}^{2} R_{d s o n s}+0.5 C_{\text {osss }} V_{M s, \max }^{2} f_{s w}+V_{g s} f_{s w} Q_{g s}$ (for $4 \mathrm{kV}$ MOSFET $M_{s}$ );

$L_{5}=p\left(i_{r m s D}^{2} R_{\text {dsons } 1}+0.5 C_{o s s s 1} V_{M s 1, \max }^{2} f_{s w}+\right.$ $V_{g s} f_{s w} Q_{g s 1}$ ) (for $p=5 \mathrm{HV}$ MOSFETs $M_{s i}, i=1,2 \ldots 5$ );

The parameters used are: $i_{\text {avg } C}=24 \mathrm{~mA}, i_{\text {avg } D}=19 \mathrm{~mA}$, $i_{r m s D}=52 \mathrm{~mA}, V_{\text {on } 2}=V_{\text {on } D b}=7 \mathrm{~V}, V_{\text {onDbs }}=1.6 \mathrm{~V}, R_{\text {dsons }}=$ $290 \Omega(4 \mathrm{kV}), R_{\text {dsons } 1}=13 \Omega, C_{\text {osss }}=19 \mathrm{pF}, C_{\text {osss } 1}=9.5 \mathrm{pF}$, $V_{M s}=3100 \mathrm{~V}, V_{M s 1}=620 \mathrm{~V}, V_{g s}=12 \mathrm{~V}, Q_{g s}=16.3 \mathrm{nC}, Q_{g s 1}=7.7$ $\mathrm{nC}$;
In the above $i_{a v g C}, i_{a v g D}, i_{r m s D}$ are the average current during charge and discharge modes, and RMS current during discharge mode, respectively. Those values are extracted from the pSpice simulations. Also $V_{\text {on } D 2}, V_{\text {on } D b}$, and $V_{\text {on } D b s}$ are the on-state diode drops of diodes $D_{2}, D_{b}$ and $D_{b s 1}$, respectively.

\section{Driving the Secondary SERIES Connected} MOSFETS USING A GATE DRIVE TRANSFORMER (GDT)

In the proposed topology as shown in Fig. 4, the secondary HV side MOSFETs, need to be driven with $p-1$ high side gate drivers, for $p$ series connected stages. It is possible to drive all secondary MOSFETs using a gate drive transformer (GDT). Figure 7a) provides the full schematic of the gate driver for 2 series connected stages $(p=2)$. The microcontroller generates enable signals for the dual low-side gate driver, whose outputs are fed to the GDT. The GDT as shown in Fig. 7a) has a single primary and two secondary windings with $1: 1$ turns ratio.

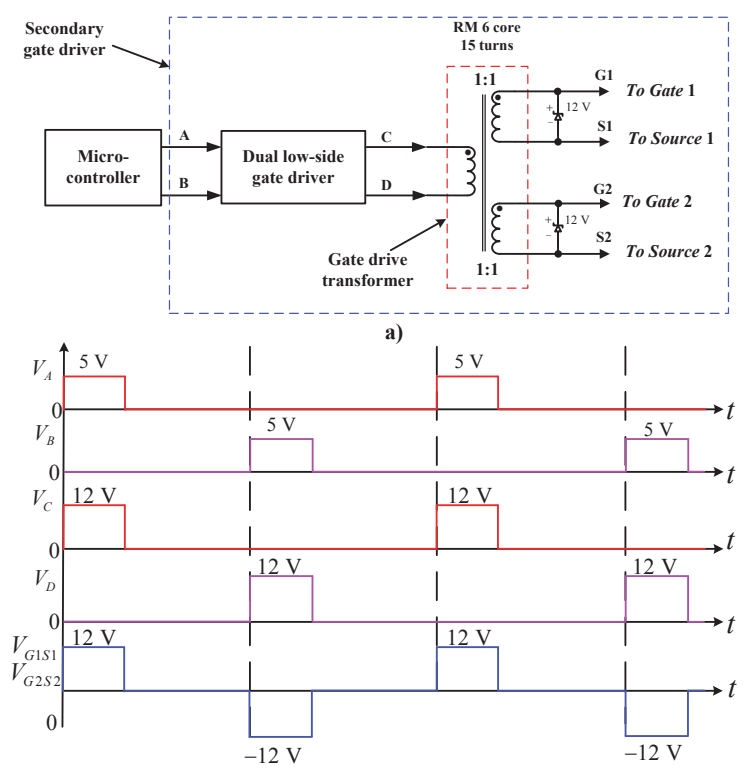

b)

Fig. 7. a) Schematic of the gate driver for driving two secondary series connected MOSFETs; b) Driving signals at different nodes in the gate driver schematic.

The GDT is made using a RM 6 core, each winding has 15 turns with $0.2 \mathrm{~mm}$ diameter. The two isolated outputs of the GDT are used to drive the 2 secondary series connected MOSFETs. To protect the secondary MOSFETs from the voltage spikes, a $12 \mathrm{~V}$ Zener diode is placed across the gate to source terminals of the two MOSFETs. Driving signals at different nodes in the secondary gate driver are shown in Fig. 7b). The two primary winding terminals of gate drive transformer (nodes C and D) are driven with two out-of-phase signals. Positive signal at the primary dot terminal of GDT (node C), produces positive gate-to-source driving signals, and positive signal at the primary non-dot terminal of GDT (node $\mathrm{D}$ ), produces negative gate-to-source driving signals, for the two MOSFETs, respectively. In Fig. 7b), $G_{1}, G_{2}, S_{1}$ and $S_{2}$ represents the gate nodes and source nodes of the two MOSFETs, respectively. The idea of driving the two series 
connected MOSFETs, using a GDT described above, can be used to drive more than 2 series connected MOSFET stages $(p>2)$. However, the type of core used for the GDT can be changed depending on the number of stages.

\section{EXPERIMENTAL RESUlTS}

The experimental prototype of the conventional HV bidirectional flyback converter is shown in Fig. 8 [35]. The experimental results showing the bidirectional operation at $2.5 \mathrm{kV}$ output voltage are provided in Fig. 9. The primary MOSFET $M_{p}$ is $250 \mathrm{~V}, 16 \mathrm{~A}$ [FQD16N25CTM], the secondary side MOSFETs are $4 \mathrm{kV}, 300 \mathrm{~mA}, 290 \Omega$ [IXTV03N400S] and $4.5 \mathrm{kV}, 200 \mathrm{~mA}, 750 \Omega$ [IXTA02N450HV], and the HV diodes $D_{2}$ and $D_{b}$ are $5 \mathrm{kV}, 150 \mathrm{~mA}$ [SXF6525]. However, for evaluating the conventional and proposed converters, only $4 \mathrm{kV}$ MOSFET is considered. The secondary MOSFET used in the proposed converter is $800 \mathrm{~V}, 1 \mathrm{~A}, 13 \Omega$ [STN1NK80Z, [46]].

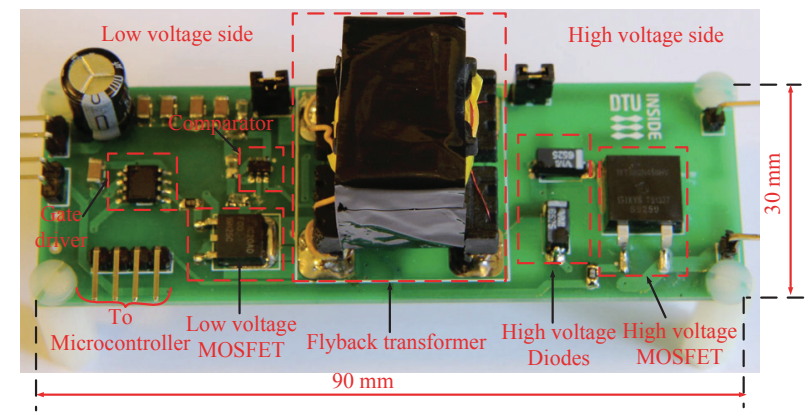

Fig. 8. Experimental prototype of the digitally controlled conventional HV bidirectional flyback converter with $4.5 \mathrm{kV}$ MOSFET on the HV side [35].

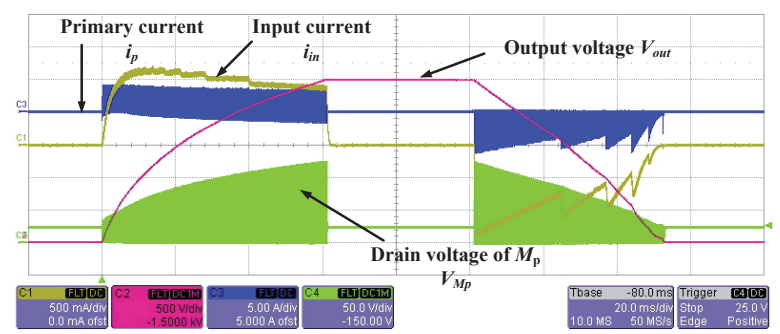

Fig. 9. Experimental results showing a single charge $(0 \mathrm{~V}$ to $2.5 \mathrm{kV})$ and discharge cycle $(2.5 \mathrm{kV}$ to $0 \mathrm{~V})$ [35]; $\mathrm{CH} 1: 500 \mathrm{~mA} / \mathrm{div}, \mathrm{CH} 2: 500 \mathrm{~V} / \mathrm{div}$, CH3: 5 A/div, CH4: $50 \mathrm{~V} /$ div, Time scale: $20 \mathrm{~ms} / \mathrm{div}$.

A digital control technique was recently proposed in [35] to achieve valley switching control during both charge and discharge processes. In Fig. 9 a full charge/discharge cycle is shown. Figure 10 confirms the valley switching operation in charge mode. However, during discharge mode the valley voltage of the drain of HV MOSFET $M_{s}$ is limited by the series connected HV diode $D_{b}$ as seen in Fig. 11. The energy efficiency measurements during both charge and discharge modes as a function of output voltage are provided in Fig. 12. The proposed converter is expected to achieve ideal valley switching during the discharge process leading to improved energy efficiency.

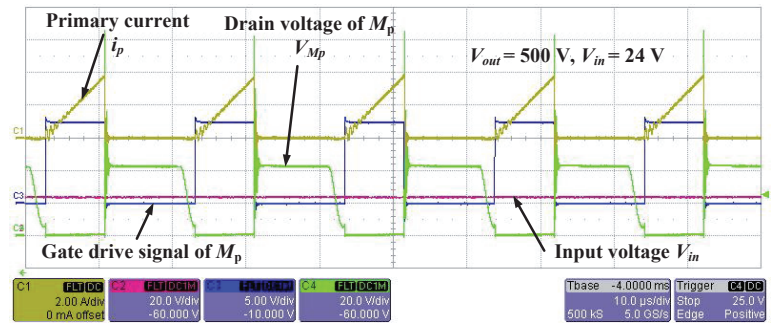

Fig. 10. Experimental waveforms when the converter is operated with valley switching during charge process; $\mathrm{CH} 1: 2 \mathrm{~A} / \mathrm{div}, \mathrm{CH} 2$ : $20 \mathrm{~V} / \mathrm{div}, \mathrm{CH} 3: 5 \mathrm{~V} / \mathrm{div}$, CH4: $20 \mathrm{~V} /$ div, Time scale: $5 \mu$ s/div.

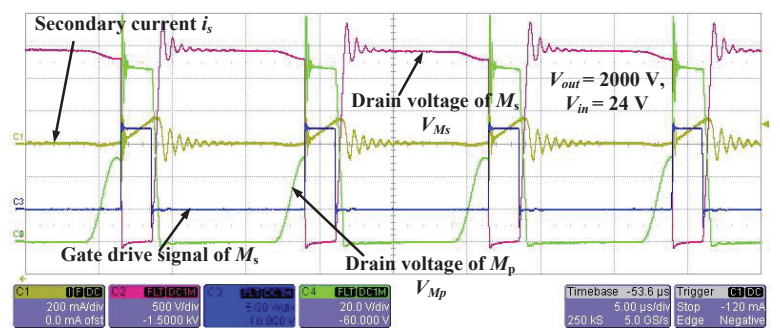

Fig. 11. Experimental waveforms when the converter is operated with valley switching during discharge process; $\mathrm{CH} 1: 200 \mathrm{~mA} / \mathrm{div}, \mathrm{CH} 2$ : $500 \mathrm{~V} / \mathrm{div}, \mathrm{CH} 3$ : $5 \mathrm{~V} /$ div, $\mathrm{CH} 4$ : $20 \mathrm{~V} /$ div, Time scale: $5 \mu \mathrm{s} /$ div.

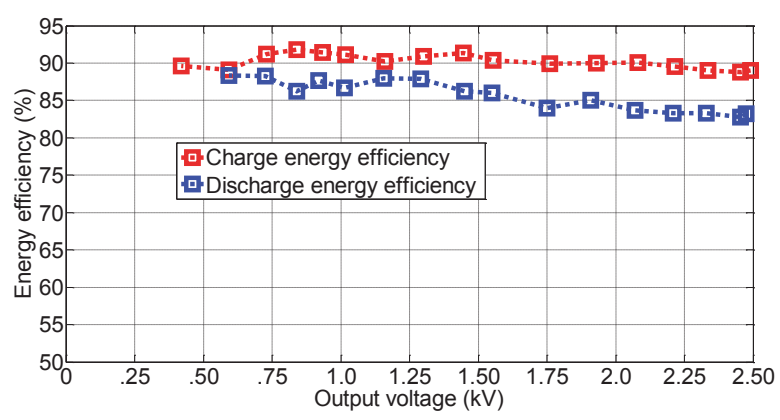

Fig. 12. Energy efficiency measurements with a $4 \mathrm{kV}$ MOSFET on HV side.

The converter specifications are provided in Table III. The details of flyback transformer are shown in Table IV. To verify the concept of proposed converter, only two series connected secondary stages are considered. The 300 secondary turns are split into two for each series connected secondary winding $\left(N_{s 1}=150\right)$. The parameters of the flyback transformer are provided in Table V. It is a non-optimized (non-interleaved, non-sectioned) transformer.

The flyback transformer used for the experiment is of noninterleaved and non-sectioned, and it is not propoerly optimized. However, for this application, transformer with multiple sections would be better choice to reduce the self-capacitance. The experimental results from the proposed converter with 2 series connected secondary stages $(p=2)$ are shown in Figs. 13,14 and 15 , respectively.

Figure 13 provides a single charge and discharge cycle using the proposed topology, when the capacitor load is charged and discharged from $0 \mathrm{~V}$ to $200 \mathrm{~V}$, and vice versa. To verify the 
proposed concept, during both charge and discharge processes, the converter is driven with fixed switching frequency. During the charge process the switching time period is $59 \mu \mathrm{s}$, and during the discharge process, the switching time period is $100 \mu$ s. In Figs. 14 and 15, a comparison of drain-to-source voltage across the two secondary MOSFETs during a charge and discharge swithcing cycle are provided.

TABLE III. CONVERTER SPECIFICATIONS

\begin{tabular}{l|l}
\hline \hline Parameter & Value \\
\hline \hline Input voltage & $24 \mathrm{~V}$ \\
\hline Capacitance of load & $400 \mathrm{nF}$ \\
\hline On-time of primary MOSFET during the charge process & $9 \mu \mathrm{s}$ \\
\hline \hline
\end{tabular}

TABLE IV. DETAILS OF THE SPLITTED FLYBACK TRANSFORMER WITH A TURNS RATIO OF 25

\begin{tabular}{l|l}
\hline \hline Parameter & Value \\
\hline \hline Number of primary / secondary turns & $12 / 300$ \\
\hline Diameter of primary / secondary winding & $0.5 \mathrm{~mm} / 0.12 \mathrm{~mm}$ \\
\hline Number of layers of primary / secondary winding & $1 / 4$ \\
\hline Type of core / material & $\mathrm{EF} 25 / \mathrm{N} 87$ \\
\hline \hline
\end{tabular}

TABLE V. PARAMETERS OF THE SPLITTED FLYBACK TRANSFORMER

\begin{tabular}{l|l}
\hline \hline Parameter & Value \\
\hline \hline Primary / Each splitted secondary magnetizing inductance & $42 \mu \mathrm{H} / 6.3 \mathrm{mH}$ \\
Secondary non-splitted magnetizing inductance & $25 \mathrm{mH}$ \\
\hline Leakage inductance referred to primary / splitted secondary & $1.1 \mu \mathrm{H} / 53 \mu \mathrm{H}$ \\
Leakage inductance referred to non-splitted secondary & $721 \mu \mathrm{H}$ \\
\hline Primary / Secondary splitted winding DC resistance & $64 \mathrm{~m} \Omega / 6.3 \Omega$ \\
Secondary non-splitted winding DC resistance & $12.4 \Omega$ \\
\hline Self-capacitance of each splitted secondary winding & $78.2 \mathrm{pF}$ \\
Self-capacitance of non-splitted secondary winding & $37 \mathrm{pF}$ \\
\hline
\end{tabular}

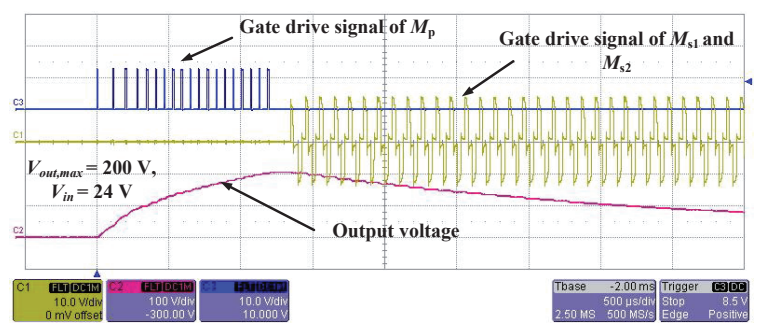

Fig. 13. A charge and discharge cycle with the proposed topology; $\mathrm{CH} 1: 10$ V/div, CH2: 100 V/div, CH3: 10 V/div, Time scale: $500 \mu$ s/div.

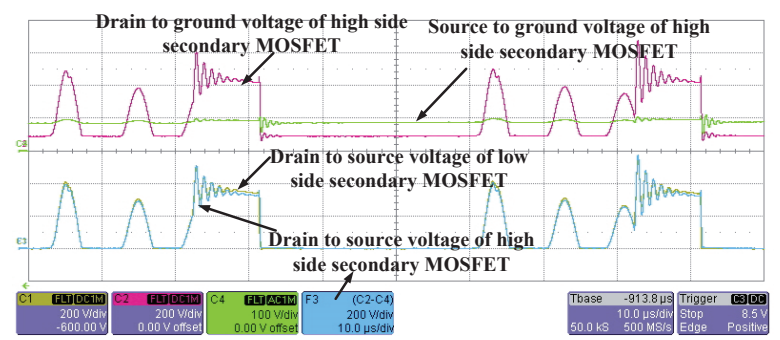

Fig. 14. Comparison of the voltage stress across the two secondary MOSFETs during the charge process using the proposed topology; $\mathrm{CH} 1: 200 \mathrm{~V} / \mathrm{div}, \mathrm{CH} 2$ : 200 V/div, CH4: 100 V/div,F3=C2-C4: 200 V/div, Time scale: $10 \mu$ s/div.

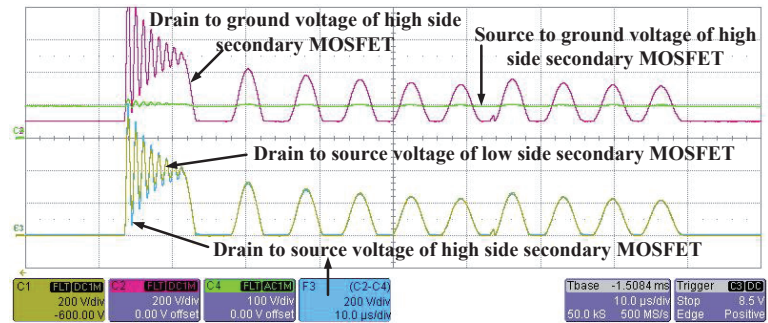

Fig. 15. Comparison of the voltage stress across the two secondary MOSFETs during the discharge process using the proposed topology; $\mathrm{CH} 1: 200 \mathrm{~V} / \mathrm{div}$, CH2: $200 \mathrm{~V} / \mathrm{div}, \mathrm{CH} 4: 100 \mathrm{~V} / \mathrm{div}, \mathrm{F} 3=\mathrm{C} 2-\mathrm{C} 4: 200 \mathrm{~V} / \mathrm{div}$, Time scale: $10 \mu \mathrm{s} / \mathrm{div}$.

\section{CONCLUSION}

In this paper, a bidirectional flyback converter with multiple series connected outputs is proposed, for high voltage drive of capacitive DEAP actuators. Simulation results (output voltages and voltage stresses across the secondary MOSFETs/diodes) during both charge and discharge processes are provided, to show a comparison between the proposed and conventional implementations. A theoretical comparison shows that the proposed converter has the potential to improve efficiency and lower the cost. The detailed implementation of secondary gate driver, using a gate drive transformer is provided. Experimental results from the conventional (for full operating voltage range $0-2.5 \mathrm{kV})$ and the proposed $(0-200 \mathrm{~V})$ bidirectional converters are provided. The experimental waveforms of the drain-tosource voltages of the two secondary MOSFETs confirms the voltage sharing across the two MOSFETs.

\section{FUTURE WORK}

Due to lack of time the converter operation for full operating voltage range, and with $p=5$ series connected secondary stages is not verified. However, the future work regarding the proposed converter involves:

- $\quad$ implementing the valley switching control during both charge and discharge processes.

- design and implementation of the gate drive transformer for $p=5$ stages.

- design of the efficient flyback trasformer with very low self-capacitance.

- $\quad$ investigating the coupling factor of different winding strategies interms of voltage sharing.

\section{REFERENCES}

[1] Y. Bar-Cohen, Electroactive Polymer [EAP] Actuators as Artificial Muscles: Reality, Potential, and Challenges, 2nd ed. Washington, DC: SPIE, 2004.

[2] R. E. Pelrine, R. D. Kornbluh, Q. Pei, and J. P. Joseph, "High-speed electrically actuated elastomers with strain greater than $100 \%$," Science, vol. 287, pp. 836-839, 2000.

[3] F. Carpi, D. DE Rossi, R. Kornbluh, R. Pelrine, and P. Sommer-Larsen, Dielectric Elastomer As Electromechanical Transducers, Amsterdam, Netherlands: Elsevier, 2008.

[4] M. Tryson, H. E. Kiil, M. Benslimane, "Powerful tubular core free dielectric electro active polymer (DEAP) push actuator," in Proc. SPIE, vol. 7287, 2009 
[5] R. Sarban, B. Lassen, M. Willatzen, "Dynamic Electromechanical Modeling of Dielectric Elastomer Actuators With Metallic Electrodes," IEEE/ASME Trans. on Mechatronics, vol. 17, no. 5, pp. 960-967, Oct. 2012 .

[6] L. Huang, P. Thummala, Z. Zhang, M. A. E. Andersen, "Battery Powered High Output Voltage Bidirectional Flyback Converter for Cylindrical DEAP Actuator,' in Proc. IEEE IPMHVC, Jun. 2012, pp. 454-457.

[7] Danfoss PolyPower, http://www.polypower.com/, [accessed 18 Nov. 2014].

[8] LEAP Technology, http://www.leaptechnology.com/, [accessed 20 Nov. 2014].

[9] P. Thummala, Z. Zhang, M. A. E. Andersen, S. Rahimullah, "Dielectric electro active polymer incremental actuator driven by multiple highvoltage bi-directional DC-DC converters," in Proc. IEEE ECCE USA, Sept. 2013, pp. 3837-3844.

[10] R. D. Kornbluh, R. Pelrine, Q. Pei, R. Heydt, S. Stanford, S. Oh, J. Eckerle,"Electroelastomers: applications of dielectric elastomer transducers for actuation, generation, and smart structures," in Proc. SPIE, vol. 4698, pp. 254-270, 2002.

[11] I. A. Anderson, T. A. Gisby, T. G. McKay, B. M. OBrien, E. P. Calius, "Multi-functional dielectric elastomer artificial muscles for soft and smart machines," Journal of Applied Physics, 112, 041101, 2012.

[12] S. K. Chung, H. B. Shin, "High-voltage power supply for semiactive suspension system with ER-fluid damper," IEEE Trans. Vehicular Technology, vol. 53, no. 1, pp. 206-214, Jan. 2004.

[13] J. Elmes, C. Jourdan, O. Abdel-Rahman, I. Batarseh, "High-Voltage, High-Power-Density DC-DC Converter for Capacitor Charging Applications," in Proc. IEEE APEC, Feb. 2009, pp. 433-439.

[14] T. Andersen, M. S. Rodgaard, O. C. Thomsen, M. A. E. Andersen, "Low voltage driven dielectric electro active polymer actuator with integrated piezoelectric transformer based driver," in Proc. SPIE Electroactive Polymer Actuators and Devices (EAPAD), vol. 7976, pp. 79762N, 2011.

[15] N. O. Sokal, R. Redl, "Control algorithms and circuit designs for optimal flyback-charging of an energy storage capacitor (e.g., for flash lamp or defibrillator)," IEEE Trans. Power Electronics, vol. 12, no. 5, pp. 885-894, Sep. 1997.

[16] R. W. Erickson and D. Maksimovic, Fundamentals of Power Electronics, 2nd ed. New York: Springer, 2001

[17] L. Eitzen, C. Graf, J. Maas, "Cascaded bidirectional flyback converter driving DEAP transducers," in Proc. IEEE IECON, Nov. 2011, pp. 1226-1231.

[18] S. H. Kang, D. Maksimovic, I. Cohen, "Efficiency Optimization in Digitally Controlled Flyback DCDC Converters Over Wide Ranges of Operating Conditions" IEEE Trans. Power Electronics, vol. 27, no. 8, pp. 3734-3748, Aug. 2012.

[19] L. Chen, H. Hu, Q. Zhang, A. Amirahmadi, I. Batarseh, "A BoundaryMode Forward-Flyback Converter With an Efficient Active LC Snubber Circuit," IEEE Trans. Power Electronics, vol. 29, no. 6, pp. 2944-2958, June 2014.

[20] J. Park, Y.-S. Roh, Y.-J. Moon, C. Yoo, "A CCM/DCM Dual-Mode Synchronous Rectification Controller for a High-Efficiency Flyback Converter," IEEE Trans. Power Electronics, vol. 29, no. 2, pp. 768774, Feb. 2014.

[21] Y.-H. Kim, Y.-H. Ji, J.-G. Kim, Y.-C. Jung, C.-Y. Won, “A New Control Strategy for Improving Weighted Efficiency in Photovoltaic AC Module-Type Interleaved Flyback Inverters," IEEE Trans. Power Electronics, vol. 28, no. 6, pp. 2688-2699, June 2013.

[22] A. Radic, A. Straka, A. Prodic, "Low-volume stackable flyback converter with near minimum deviation controller," in Proc. IEEE APEC, March 2014, pp. 1948-1953.

[23] J.-W. Shin, S.-J. Choi, B.-H. Cho, "High-Efficiency Bridgeless Flyback Rectifier With Bidirectional Switch and Dual Output Windings," IEEE Trans. Power Electronics, vol. 29, no. 9, pp. 4752-4762, Sept. 2014.

[24] N. Sukesh, M. Pahlevaninezhad, P. K. Jain, "Analysis and Implementation of a Single-Stage Flyback PV Microinverter With Soft Switching," IEEE Trans. Industrial Electronics, vol. 61, no. 4, pp. 1819-1833, April 2014.

[25] K. Venkatesan, "Current mode controlled bidirectional flyback converter," in Proc. IEEE PESC, pp. 835-842 vol.2, 26-29 Jun 1989.
[26] T. Bhattacharya, V. S. Giri, K. Mathew, L. Umanand, "Multiphase Bidirectional Flyback Converter Topology for Hybrid Electric Vehicles" IEEE Trans. Industrial Electronics, vol. 56, no. 1, pp.78-84, Jan. 2009.

[27] T. Anno, H. Koizumi, "Double Input Bidirectional DC/DC Converter Using Cell Voltage Equalizing with Flyback Transformer," IEEE Trans. Power Electronics, April 2014

[28] G. Chen, Y.-S. Lee, S.Y.R. Hui, D. Xu, Y. Wang, "Actively clamped bidirectional flyback converter," IEEE Trans. Industrial Electronics, vol. 47, no. 4, pp. 770-779, Aug. 2000

[29] F. Zhang, Y. Yan, "Novel ForwardFlyback Hybrid Bidirectional DC DC Converter," IEEE Trans. Industrial Electronics, vol. 56, no. 5, pp 1578-1584, May 2009.

[30] P. Thummala, Z. Zhang, M. A. E. Andersen, "High Voltage Bidirectional Flyback Converter for Capacitive Actuator," in Proc. European Power Electronics (EPE) Conference, Sept. 2013, pp. 1-10.

[31] L. Huang, Z. Zhang, M.A.E. Andersen, "Design and development of autonomous high voltage driving system for DEAP actuator in radiator thermostat," in Proc. IEEE APEC, pp. 1633-1640, 16-20 March 2014

[32] P. Thummala, H. Schneider, Z. Zhang, A. Knott, M. A. E. Andersen, "Optimization of a bi-directional flyback converter for a high voltage capacitor charging application," in Proc. IEEE APEC, Mar. 2014, pp. $2556-2563$.

[33] P. Thummala, H. Schneider, Z. Zhang, Z. Ouyang, A. Knott, M. A. E. Andersen, "Efficiency Optimization by Considering the High Voltage Flyback Transformer Parasitics using an Automatic Winding Layout Technique," IEEE Trans. Power Electronics, accepted, 2014.

[34] H. Schneider, P. Thummala, L. Huang, Z. Ouyang, A. Knott, Z. Zhang, M. A. E. Andersen, "Investigation of transformer winding architecture for high voltage capacitor charging applications," in Proc. IEEE APEC, Mar. 2014, pp. 334-341

[35] P. Thummala, D. Maksimovic, Z. Zhang, M. A. E. Andersen, "Digital control of a high-voltage $(2.5 \mathrm{kV})$ bidirectional DC-DC converter for driving a dielectric electro active polymer (DEAP) based capacitive actuator," in Proc. IEEE ECCE USA, Sept. 2014, pp. 3435-3442.

[36] R. Pittini, L. Huang, Z. Zhang, M. A. E. Andersen, "Primary parallel secondary series flyback converter (PPSSFC) with multiple transformers for very high step-up ratio in capacitive load charging applications," in Proc. IEEE APEC, Mar. 2014, pp. 1440-1447.

[37] IXYS, Online available, http://ixapps.ixys.com/DataSheet/ DS100214A-(IXTH_V03N400_S).pdf, [accessed 18 Nov. 2014].

[38] VMI, Online available, http://www.voltagemultipliers.com/pdf/ SXF6521_25.pdf, [accessed 18 Nov. 2014].

[39] J.-W. Kim, J.-S. Yon, B.-H. Ch, "Modeling, control, and design of inputseries-output-parallel-connected converter for high-speed-train power system," IEEE Trans. Industrial Electronics, vol. 48, no. 3, pp. 536-544, Jun 2001.

[40] R. Ayyanar, R. Giri, N. Mohan, "Active input-voltage and load-current sharing in input-series and output-parallel connected modular DC-DC converters using dynamic input-voltage reference scheme," IEEE Trans. Power Electronics, vol. 19, no. 6, pp. 1462-1473, Nov. 2004.

[41] J. W. Kimball, J. T. Mossoba, P. T. Krein, "Control Technique for Series Input-Parallel Output Converter Topologies" in Proc. IEEE PESC pp 1441-1445, June 2005.

[42] X. Ruan, W. Chen, L. Cheng, C.K. Tse, H. Yan, T. Zhang, "Control Strategy for Input-SeriesOutput-Parallel Converters," IEEE Trans. Industrial Electronics, vol. 56, no. 4, pp. 1174-1185, April 2009.

[43] H. Fan, H. Li, "A distributed control of input-series-output-parallel bidirectional dc-dc converter modules applied for $20 \mathrm{kVA}$ solid state transformer," in Proc. IEEE APEC, pp. 939-945, 6-11 March 2011.

[44] P. Thummala, D. Maksimovic, Z. Zhang, M. A. E. Andersen, R. Sarban, "Design of a High Voltage DC-DC Converter for Driving the Capacitive Incremental Actuators usable in Electric Vehicles (EVs)," in Proc. IEEE IEVC, Dec. 2014

[45] P. Thummala, Z. Zhang, M. A. E. Andersen, R. Sarban, "Parallel input parallel output high voltage bi-directional converters for driving dielectric electro active polymer actuators," in Proc. SPIE EAPAD, vol. 9056, pp. 90561N-90561N-15, Mar. 2014.

[46] STM, Online available, http://www.st.com/st-web-ui/static/active/en/ resource/technical/document/datasheet/CD00058073.pdf, [accessed 18 Nov. 2014]. 